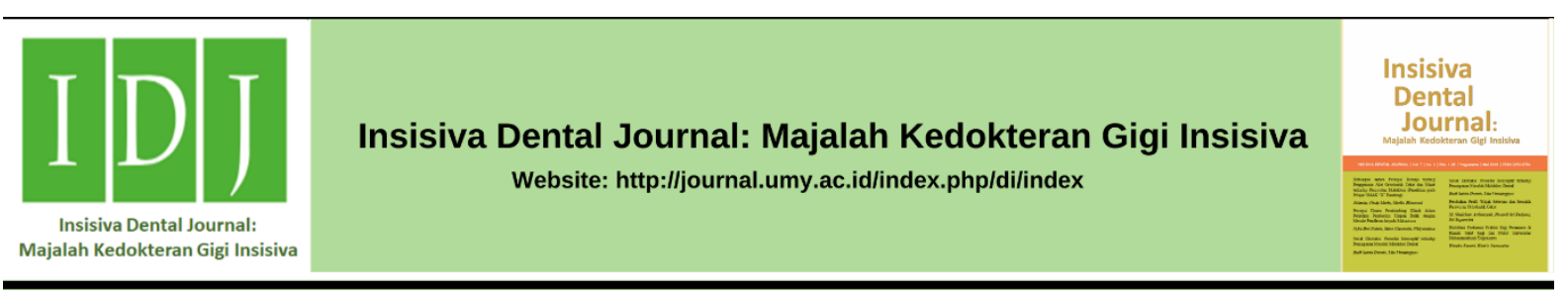

Research Article

\title{
Resin Akrilik Reinforce Nanosisal Menurunkan Perlekatan Bakteri Steptococcus mutans dan Jamur Candida albicans
}

Acrylic Resin Reinforce with Nanosisal Reduces The Attachment of S. mutans Bacteria and Candida Albicans Fungal

Dwi Aji Nugroho*, Tiara Chaesar Yusifar, Ita Nur Rochmah, Hairiyah

Departemen Dental Material, Program Studi Kedokteran Gigi, Fakultas Kedokteran dan Ilmu Kesehatan, Universitas Muhammadiyah Yogyakarta, Jalan Brawijaya, Tamantirto, Kasihan, Bantul, Daerah Istimewa Yogyakarta 55183, Indonesia

Received date: December $27^{\text {th }}, 2019$; revised date: July $24^{\text {th }}, 2021$; accepted: November $25^{\text {th }}, 2021$

DOI: $10.18196 /$ di.v10i1.7353

\begin{abstract}
Abstrak
Resin akrilik telah banyak digunakan sebagai bahan basis gigi tiruan lepasan sejak pertengahan tahun 1940. Nanosisal merupakan serat dari tanaman Agave sisalana yang dibuat berukuran nano karena dapat memberikan hasil pemolesan gigi tiruan yang lebih halus, memudahkan proses polishing, tahan terhadap keausan, lebih mengkilap sehingga perlekatan bakteri dan jamur lebih sedikit. Penelitian ini bertujuan untuk mengetahui pengaruh nanosisal dengan konsentrasi $0 \%, 10 \%$ dan 20\% yang dicampur dengan material resin akrilik terhadap perlekatan S. mutans dan $C$. albicans. Jenis penelitian ini adalah penelitian eksperimental in vitro. Pembuatan nanosisal $0 \%, 10 \%$, dan $20 \%$ dicampur dengan resin akrilik polimerisasi panas dan dicetak dengan ukuran $15 \times 15 \times 2 \mathrm{~mm}$, direndam dalam suspensi $S$. mutans dan $C$. albicans kemudian dihitung jumlah koloninya untuk menentukan perlekatannya. Perhitungan koloni dilakukan pada hasil biakan $S$. mutans dalam media TSA dan $C$. albicans dalam media SDA. Hasil penelitian menunjukkan tidak terdapat perbedaan yang bermakna pada perlekatan $S$. mutans terhadap penambahan jumlah nanosisal ( $>>0,05)$ sedangkan hasil uji perlekatan $C$. albicans menunjukkan perbedaan yang bermakna $(\mathrm{p}<0,05)$ sehingga dapat disimpulkan terdapat penurunan perlekatan $C$. albicans pada resin akrilik yang diberi reinforced nanosisal. Semakin tinggi konsentrasi nanosisal yang ditambahkan maka semakin menurunkan jumlah perlekatan koloni S. mutans dan C. albicans pada sampel resin akrilik.
\end{abstract}

Kata Kunci: Agave sisalana; Nanosisal; Perlekatan S. mutans; C. Albicans; Resin akrilik

\begin{abstract}
Acrylic resin has been widely used as a removable denture base material since the mid-1940s. Nanosisal is a natural fiber from the Agave sisalana made in nanosize. It can provide smoother denture polishing results, facilitate the polishing process, be resistant to wear and be glossier to make the adhesion smooth, leading to fewer bacteria and fungi. This study aims to determine the effect of nanosisal with concentrations of 0\%, 10\% and $20 \%$ mixed with acrylic resin material on the attachment of $S$. Mutans and C. Albicans. This research is experimental in vitro study. Preparation of nanosisal 0\%, 10\%, and 20\% was mixed with hot polymerized acrylic resin and printed with a size of $15 \times 15 \times 2 \mathrm{~mm}$, immersed in a suspension of $S$. mutans and $C$. Albicans. Furthermore, the number of colonies was counted to determine the attachment. Colony counts were performed on the cultured $S$. Mutans in TSA media and C. Albicans in SDA media. The results showed no significant difference in the attachment of $S$. mutans to the increase in the number of nanosisals ( $p>0.05)$. Meanwhile, the results of the $C$. Albicans attachment test showed a significant difference ( $p<0.05)$; thus, it could be concluded that there was a decrease in the attachment of $C$. Albicans on nanoscale reinforced acrylic resin. In other words, the higher the concentration of nanosisal was added, the lower the number of colonies of S. mutans and C. Albicans was attached to the acrylic resin sample.
\end{abstract}

Keywords: Acrylic resin; Agave sisalana; Attachment of S. mutans; C. Albicans; Nanosisal.

\footnotetext{
* Corresponding author, e-mail: dwiajidrg@umy.ac.id
} 


\section{PENDAHULUAN}

Resin akrilik telah banyak digunakan sebagai bahan basis gigi tiruan lepasan sejak pertengahan tahun 1940. Pemakaian gigi tiruan akrilik dapat menyebabkan ketidaknyamanan dan iritasi mukosa apabila kebersihan gigi tiruan tidak dijaga sehingga berakibat pada terpaparnya flora mikroba mulut seperti bakteri, virus, dan jamur. Saat ini resin akrilik masih digunakan sebagai bahan pilihan untuk pembuatan basis gigi tiruan karena memiliki beberapa kelebihan diantaranya harganya murah, mudah direparasi, proses pembuatannya mudah, menggunakan peralatan yang sederhana, serta memiliki warna stabil dan mudah dipoles, namun resin akrilik juga memiliki beberapa kekurangan, diantaranya adalah mudah patah baik di dalam maupun di luar mulut. 1 , 2

Resin akrilik dibedakan atas tiga jenis yaitu resin akrilik swapolimerisasi, resin akrilik polimerisasi sinar dan resin akrilik polimerisasi panas (RAPP). Masingmasing menggunakan energi gelombang mikro, sinar, dan energi panas berupa perendaman air maupun oven gelombang mikro untuk polimerisasi. Ada empat tahapan terjadinya proses polimerisasi yaitu tahap aktivasi. Inisiasi, propagasi dan terminasi. Pertama yaitu tahap aktivasi merupakan langkah pertama yang melibatkan aktivasi radikal bebas. Kedua tahap inisiasi terjadi kombinasi radikal bebas dengan monomer untuk menciptakan rantai awal. Tahap ketiga adalah propagasi, monomer-monomer yang sudah diaktifkan akan saling berikatan sehingga terbentuknya polimer dengan jumlah monomer tertentu. Tahap terakhir adalah tahap terminasi, dimana terbentuknya rantai molekul yang stabil. $, \underline{2}, \underline{3}$

Resin akrilik juga rentan terhadap perlekatan mikroorganisme, seperti bakteri, jamur, dan virus. Jamur adalah salah satu penyebab terjadinya denture stomatitis. $1, \underline{3}, 4, \underline{5}$ Berbagai metode dapat dilakukan untuk mengatasi masalah tersebut salah satunya yaitu dengan menggunakan serat alam.
Serat alam memiliki kandungan antibakteri dan antijamur. Serat alami merupakan biomaterial yang cukup menjanjikan oleh karena sifat biokompatibilitas dan young's modulus serta kekuatan tarik yang lebih tinggi daripada bahan basis gigi tiruan. ${ }^{1}$ Terdapat beberapa serat dari serat alam dengan potensi reinforcement yang dibagi menjadi dua kelompok besar yaitu serat kayu dan non kayu. Beberapa serat non kayu misalnya rami, kenaf, lenan dan sisal yang digunakan secara komersial dalam aplikasi resin akrilik. Serat rumput alam juga menjadi perhatian para peneliti sebagai serat penguat atau reinforce dalam aplikasi resin akrilik. Serat jerami dari beras, gandum dan jagung tersedia secara luas di berbagai belahan dunia dapat digunakan sebagai reinforce yang murah untuk aplikasi resin akrilik. Serat kayu daur ulang seperti serat koran juga menjadi sumber potensial sebagai reinforce dalam pengaplikasian resin akrilik. $\underline{6}$

Sisal merupakan salah satu serat alam yang paling banyak digunakan dan mudah dibudidayakan. Keunggulan lain dari sisal berupa kekuatan yang baik, tahan lama, stretch dan afinitas terhadap zat warna baik. Penelitian lain juga menggunakan serat sisal sebagai bahan penguat resin komposit, serat sisal dibuat dengan ukuran diameter 0,2-0,4 $\mathrm{mm}$. Dalam dunia Kedokteran Gigi, serat sisal juga dapat digunakan sebagai alternatif pilihan bahan penguat basis gigi tiruan resin akrilik. $\cdot$, $, 8,9$

Tanaman sisal (Agave sisalana) merupakan tanaman yang mempunyai serat yang kuat dan mudah dibudidayakan serta berperan sebagai antijamur, antibakteri, dan aktivitas sitotoksik. Komposisi biofiber sisal terdiri dari $78 \%$ selulosa, $19 \%$ hemiselulosa, $8 \%$ lignin, $10-22 \%$ pelembab dan 3\% lain-lain. Agave sisalana juga kaya akan saponin yang merupakan metabolit sekunder. Steroidal saponin diketahui memiliki kemampuan sebagai antijamur, antibakteri dan aktivitas sitotoksik. Agave sisalana juga mengandung homoisoflavonoid dan flavonoid yang memiliki 
efek immunemodulatory, flavonoid menyebabkan terjadinya kerusakan permeabilitas dinding sel bakteri, mikrosom, dan lisosom sebagai hasil interaksi antara flavonoid dengan DNA bakteri. $\underline{10}$

Teknologi nano dipergunakan pada bahan-bahan kedokteran gigi seperti bahan tambal komposit, bahan adhesif, bahan cetak, dental implan, kawat ortodonti dan pasta gigi. Teknologi nano mengembangkan bahan dalam bentuk partikel berukuran nano untuk mendapatkan produk-produk yang lebih baik. Dalam praktiknya terdapat fakta bahwa semakin besar ukuran yang diberikan pada material kedokteran gigi dapat membuat permukaan produk yang kasar. Apabila permukaan produk yang kasar diaplikasikan dalam rongga mulut maka dapat memicu pembentukan plak yang menyebabkan oral hygiene buruk. ${ }^{4}$ Serat sisal dibuat berukuran nano karena dapat memberikan hasil pemolesan gigi tiruan yang lebih halus, memudahkan proses polishing, tahan terhadap keausan, lebih mengkilap sehingga perlekatan bakteri dan jamur lebih sedikit.

Penelitian ini dilakukan untuk mengetahui pengaruh penambahan nanosisal pada material resin akrilik terhadap perlekatan bakteri S. mutans dan C. albicans.

\section{MATERIAL DAN METODE}

Penelitian ini adalah penelitian eksperimental in vitro. Sebanyak enambelas sampel Resin Akrilik Polimerisasi Panas (RAPP) dibuat dengan ukuran $15 \times 15 \times 2$ $\mathrm{mm}$. Sampel dibagi menjadi dua kelompok besar yaitu delapan resin akrilik tanpa modifikasi nanosisal dan delapan resin akrilik dengan modifikasi nanosisal. Pada setiap kelompok besar empat sampel diuji perlekatan S. mutans dan empat sampel uji perlekatan C. albicans.

Pembuatan nanosisal dilakukan dengan memotong tanaman Agave sisalana (sisal) menjadi beberapa bagian hingga beratnya mencapai 3 gram. Serat kemudian di alkalisasi dengan merendam pada $\mathrm{Na}$ $(\mathrm{OH})_{2}$ dengan suhu $100^{\circ} \mathrm{C}$ selama dua jam sambil diaduk menggunakan magnetic stirrer. Perlakuan ini diulang selama 3 kali. Serat kemudian disaring dan dicuci dalam akuades, sebelum di bleaching menggunakan larutan campuran $\mathrm{Na}(\mathrm{OH})_{2}, \mathrm{H}_{2} \mathrm{O}_{2}$ dan akuades. Proses bleaching dilakukan pada suhu $80^{\circ} \mathrm{C}$ selama dua jam sambil diaduk menggunakan magnetic stirrer. Proses bleaching diulang selama empat kali. Setelah proses bleaching, serat di saring dan dicuci dalam akuades kemudian diproses menggunakan ultrasonik mesin (Cole-Parmer Prosesor Ultrasonik, Model CP 505., USA). Serat sisal yang diperoleh disaring dengan filter glass frit No. 1 untuk menghilangkan residu agregat dan kemudian dikeringkan dalam pengering beku (Flex-DryTM $\mu$ PMicroprocessor Control, FTS Systems, Inc., USA) untuk mendapatkan serat nanosisal yang padat. Serat sisal padat kemudian diamati melalui mikroskop elektron (SEM) untuk menentukan ukurannya.

Pembuatan sampel RAPP dilakukan dengan mencampurkan powder dan liquid di dalam stelon pot hingga fase dough. Adonan RAPP kemudian dimasukkan ke dalam cetakan logam ukuran $15 \times 15 \times 2 \mathrm{~mm}$ yang sudah tertanam di dalam kuvet yang berisi plaster of paris hingga adonan dalam cetakan mengeras, lalu dilakukan pengolesan Cold Mould Seal (CMS) agar mudah dilepas dari cetakan setelah perebusan. Kertas selopan diletakkan di atas adonan sebelum ditutup dengan kuvet kontra. Kuvet diisi dengan adonan plaster of paris hingga penuh. Pengaplikasian tekanan pada kuvet menggunakan press ulir untuk mengeliminasi kelebihan plaster of paris lalu dilakukan perebusan adonan ke dalam waterbath dengan suhu $74^{\circ 0} \mathrm{C}$ selama 2 jam dan $100^{\circ} \mathrm{C}$ selama 1 jam. Finishing dilakukan untuk mendapatkan permukaan yang halus dan penghilangan bagian yang tajam menggunakan arkansas stone yang dibubuhi pumice yang dicampur dengan alkohol. Polishing menggunakan felt cone yang dibubuhi kryt dan air untuk 
mendapatkan permukaan sampel RAPP yang halus dan mengkilat. Sampel resin akrilik yang telah di finishing dan polishing bisa dilihat pada gambar 1 .

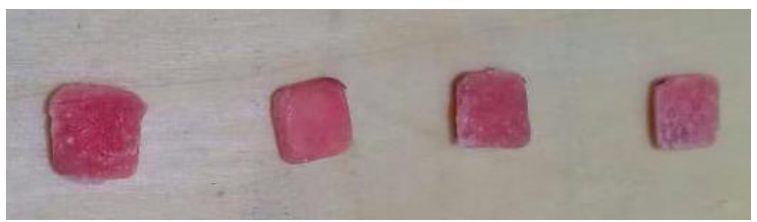

Gambar 1. Sampel resin akrilik

Sampel RAPP dengan modifikasi nanosisal 0\%, 10\%, dan 20\% direndam ke dalam saliva sintetis selama 1 jam seperti agar terbentuk pelikel sehingga memudahkan perlekatan bakteri dan jamur pada sampel. Satu jam kemudian, sampel diambil kemudian masing- masing sampel dimasukkan ke dalam suspensi $S$. mutans dan C. albicans selama 24 jam dengan suhu inkubator $37^{\circ 0} \mathrm{C}$ (Gambar 2 dan 3). Sampel diambil dari inkubator setelah 24 jam kemudian dimasukkan ke dalam $10 \mathrm{ml}$ saline $(\mathrm{NaCl}$ 0,9\%) dan diaduk dengan vortex mixer hingga homogen. Larutan diambil 0,1 ml lalu ditanamkan ke dalam media TSA pada cawan petri untuk uji perlekatan $S$. mutans dan $0,1 \mathrm{ml}$ ditanamkan ke dalam media SDA pada cawan petri untuk uji perlekatan $C$. albicans. Inkubasi pembenihan $S$. mutans pada inkubator dengan suhu $37^{\circ} \mathrm{C}$ selama 24 jam sedangkan untuk inkubasi $C$. albicans selama 48 jam. Langkah terakhir yaitu penghitungan jumlah koloni dengan menggunakan colony counter.

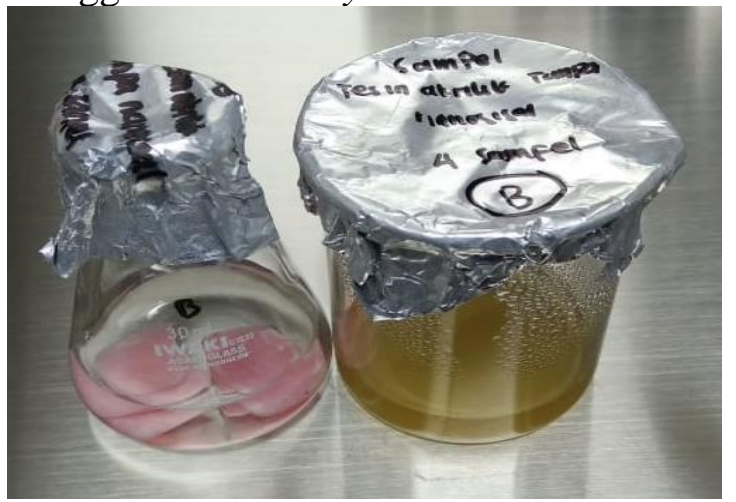

Gambar 2. Perendaman sampe kedalam suspensi $S$. mutans.

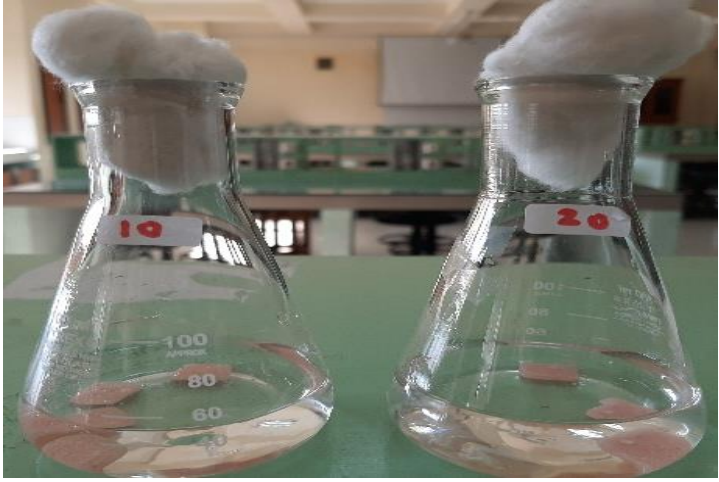

Gambar 3. Perendaman sampel kedalam suspensi C. albicans.

\section{HASIL}

Berikut hasil uji perlekatan jumlah koloni bakteri $S$. mutans dan $C$. albicans pada sampel resin akrilik nanosisal dengan konsentrasi $0 \%, 10 \%, 20 \%$. Tabel 1 menunjukkan nilai rata-rata perhitungan perlekatan bakteri pada resin akrilik tanpa nanosisal $(0 \%)$ yaitu 317 koloni, resin akrilik dengan nanosisal $10 \%$ yaitu 314 koloni, dan resin akrilik dengan nanosisal $20 \%$ yaitu 269 koloni.

Tabel 1. Hasil perhitungan perlekatan bakteri

\begin{tabular}{cccc}
\hline \multicolumn{4}{c}{ Rata-rata Koloni Bakteri } \\
\hline & Resin & Resin & Resin \\
& Akrilik & Akrilik & Akrilik \\
& Tanpa & dengan & dengan \\
& Nanosisal & Nanosisal & Nanosisal \\
& $(0 \%)$ & $10 \%$ & $20 \%$ \\
\hline Mean & 317 & 314 & 269 \\
\hline
\end{tabular}

Hasil rata-rata perlekatan jamur pada resin akrilik tanpa nanosisal $(0 \%)$ yaitu 408 koloni, resin akrilik dengan nanosisal $10 \%$ yaitu 256 koloni, dan resin akrilik dengan nanosisal 20\% yaitu 104 koloni ditunjukkan Tabel 2.

Tabel 2. Hasil perhitungan perlekatan jamur

\begin{tabular}{cccc}
\hline \multicolumn{4}{c}{ Rata-rata Koloni Jamur } \\
& Resin & Resin & Resin \\
& Akrilik & Akrilik & Akrilik \\
& Tanpa & dengan & dengan \\
& Nanosisal & Nanosisal & Nanosisal \\
& $(0 \%)$ & $10 \%$ & $20 \%$ \\
\hline Mean & 408 & 256 & 104 \\
\hline
\end{tabular}

Data yang didapatkan dari uji oneway Anova menunjukkan nilai signifikansi untuk perlekatan bakteri dan jamur yaitu 
0.360 dan 0.000 . Pada perlekatan bakteri nilai sig. $>0.05$ dan nilai $\mathrm{F}$ table $>\mathrm{F}$ hitung maka H0 diterima sehingga dapat disimpulkan bahwa tidak terdapat perbedaan yang bermakna pada perlekatan bakteri terhadap penambahan jumlah nanosisal. Dengan tidak adanya perbedaan yang bermakna maka tidak perlu dilakukan uji lanjutan yaitu post hoc. Perlekatan jamur dengan nilai sig. $<0.05$ dan $\mathrm{F}$ tabel $<\mathrm{F}$ hitung maka $\mathrm{H} 0$ ditolak dan $\mathrm{H} 1$ diterima sehingga dapat disimpulkan bahwa terdapat perbedaan yang bermakna pada perlekatan jamur terhadap penambahan jumlah nanosisal, lalu untuk membandingkan perbedaan bermakna antar kelompok perlakuan dilanjutkan dengan uji post hoc Bonferroni. Hasil ditunjukkan pada tabel 3.

Tabel 3. Hasil uji post hoc Bonferroni

\begin{tabular}{lll}
\hline $\begin{array}{l}\text { Konsentrasi } \\
\text { Nanosisal }\end{array}$ & $\begin{array}{l}\text { Konsentrasi } \\
\text { Nanosisal }\end{array}$ & Sig. \\
\hline $0 \%$ & $10 \%$ & 0.015 \\
\hline & $20 \%$ & 0.000 \\
\hline $10 \%$ & $0 \%$ & 0.015 \\
\hline $20 \%$ & $20 \%$ & 0.015 \\
\hline & $0 \%$ & 0.000 \\
\hline
\end{tabular}

Hasil uji post hoc Bonferroni didapatkan hasil bahwa semua data diketahui terdapat perbedaan yang bermakna pada nanosisal $0 \%$ terhadap $10 \%$, $0 \%$ terhadap $20 \%$, dan $10 \%$ terhadap $20 \%(\mathrm{p}<0,05)$.

\section{PEMBAHASAN}

Hasil penelitian ini menunjukkan bahwa terjadi penurunan koloni bakteri dan jamur pada penambahan konsentrasi nanosisal. Hasil penurunan jumlah koloni bakteri pada resin akrilik tanpa nanosisal, resin akrilik dengan nanosisal $10 \%$ dan resin akrilik dengan nanosisal $20 \%$ adalah 317, 314 dan 269. Rata-rata penurunan jumlah koloni bakteri pada resin akrilik tanpa nanosisal dibandingkan dengan resin akrilik dengan nanosisal $10 \%$ tidak memiliki perbedaan yang besar, namun jika resin akrilik tanpa nanosisal dibandingkan dengan resin akrilik nanosisal $20 \%$ memiliki perbedaan yang cukup besar. Hal ini menunjukkan kandungan antibakteri pada nanosisal dapat menurunkan perlekatan bakteri. Semakin tinggi konsentrasi nanosisal yang ditambahkan pada resin akrilik dapat menurunkan perlekatan bakteri Streptococcus mutans. Kandungan antibakteri berupa flavonoid pada sisal merupakan golongan senyawa fenol. Flavonoid mampu membentuk senyawa kompleks dengan protein melalui ikatan hidrogen sehingga pengendapan protein ini dapat menghambat pertumbuhan plak yang merupakan media perlekatan bakteri. Apabila dibandingkan penurunan jumlah koloni bakteri pada resin akrilik dengan nanosisal 20\% lebih besar dari resin akrilik dengan nanosisal 10\%, peningkatan konsentrasi diduga mampu menambah daya antibakteri dari nanosisal. $\underline{11}$

Kandungan antibakteri selain flavonoid pada nanosisal adalah tanin. Mekanisme tanin sebagai antibakteri melalui perusakan membran sel bakteri karena toksisitas tanin dan pembentukan ikatan komplek ion logam dari tanin yang berperan dalam toksisitas tanin. Bakteri anaerob memerlukan zat besi untuk berbagai fungsi salah satu nya untuk reduksi dari prekursor ribonukleotida DNA. Adanya ikatan tanin dan besi akan menyebabkan terganggunya berbagai fungsi bakteri. $\underline{12}$

Ekstrak etanol daun sisal juga mempunyai kandungan saponin yang merupakan senyawa aktif bersifat antibakteri. Mekanisme kerja saponin sebagai antibakteri yaitu dengan cara meningkatkan permeabilitas membran sel menjadi tidak stabil sehingga menyebabkan hemolisis sel. Saponin terbukti efektif dalam menghambat pertumbuhan bakteri gram positif. Serat sisal juga memiliki kandungan flavonoid. Flavonoid mempunyai sifat toksik terhadap sel kanker, menghambat pelepasan histamin, anti jamur dan anti bakteri. Mekanisme kerja flavonoid dengan cara membentuk senyawa kompleks yang dapat 40 mengganggu keutuhan membran sel bakteri dengan 
protein ekstraseluler melalui cara denaturasi protein sel bakteri dan merusak membran sel tanpa bisa diperbaiki. $\underline{13}, 14$

Hasil penurunan jumlah koloni jamur pada resin akrilik tanpa nanosisal, resin akrilik dengan nanosisal $10 \%$ dan resin akrilik dengan nanosisal $20 \%$ adalah 408, 256 dan 104. Rata-rata penurunan jumlah koloni jamur pada resin akrilik dengan nanosisal $10 \%$ dan $20 \%$ mengalami penurunan yang cukup besar jika dibandingkan dengan kelompok resin akrilik tanpa nanosisal.

Menurut penelitian Jenner dkk. (2009), zat antifungal di dalam serat sisal yaitu saponin. Saponin bekerja dengan cara menghancurkan integritas dari membran sel jamur yaitu sterol. Gugus hidroksil saponin akan berikatan dengan gugus hidroksil pada membran sterol sel Candida albicans sehingga kehilangan integritas membran. Selain faktor biologis, adapun faktor fisik yang dapat menurunkan jumlah koloni jamur yakni terkait pemolesan dan pemilihan bahan nanomaterial pada basis gigi tiruan. $\frac{15}{}$

Lempeng akrilik merupakan bahan basis gigi tiruan yang memiliki sifat fisik seperti porositas, penyerapan air dan kekasaran permukaan. Tekstur permukaan berpengaruh terhadap akumulasi plak pada basis gigi tiruan. Semakin kasar permukaan resin akrilik maka perlekatan plak pada basis gigi tiruan semakin meningkat. Penelitian menunjukkan bahwa permukaan sampel resin akrilik dengan penambahan nanosisal memiliki tekstur yang lebih halus dibandingkan dengan resin akrilik tanpa nanosisal. Permukaan yang lebih halus tersebut membuat jamur cenderung lebih sulit untuk melekat. Sisal yang dibuat berukuran nano tersebut ketika ditambahkan dengan material resin akrilik juga memberikan kemudahan dalam melakukan finishing dan polishing. Kekasaran permukaan pada resin akrilik merupakan sifat fisis yang dapat mempengaruhi perlekatan Candida albicans. Dalam penelitian lain menjelaskan senyawa flavonoid dari berbagai tumbuhan mempunyai aktivitas biologi yang menarik, seperti bersifat toksik terhadap sel kanker, menghambat pelepasan histamin, anti jamur dan anti bakteri. $\underline{16}$

\section{KESIMPULAN}

Kesimpulan penelitian ini adalah terdapat penurunan perlekatan Candida Albican pada resin akrilik yang diberi reinforced nanosisal.

DAFTAR PUSTAKA

1. Putri ML, Sugiatno E, Kusuma HA. Pengaruh jenis fiber dan surface treatment ethyl acetate terhadap kekuatan fleksural dan impak pada preparasi plat gigi tiruan resin akrilik. $J$ Ked Gigi. 2016;7(2):111-117.

2. Ganesh S, Gujjari AK, Kumar S, Ravi MB, Sownya S, Meenakshi S. Comparative Study to Assess the effectiveness of Various Disinfectans on Two Microorganisms and the effect of the Same Flexural Strength of Acrylic denture Base Resin - An in Vitro Study. J Int Oral Health, 2016;5(3):55-62.

3. Heymann HO, Swift EJ, Ritter AV. Sturdevants Art and Science of Operative Dentistry $7^{\text {th }}$ Edition. Elsevier; 2019;171.

4. Agular FHB, Olivera TRVE, Lima DANL, Paulillo LAMS, Lovadino JR. Effect of Light Curing Modes And Ethanol Immersion Media on The Susceptibility Of a Microhybrid Composite Resin to Staining. J Appl Oral Sci. 2007;15(2):105-109. https://doi.org/10.1590/S167877572007000200006

5. Jain D, Shakya P. An in nitro study on effect of delmopinol application on Candida albicans adherence on heat cured dental base Acrylic resin: althorough study. Indian Jour Dentl Res.2013;24(5):645.

https://doi.org/10.4103/09709290.123423 
6. Srividya NCK, Shetty J. Effect of different polishing agents on surface finish and hardness of denture base acrylic resins : a comparative study. $J p$ journals. 2013;1(1):7-11.

7. Mohanty AK, Misra M, Drzal LT. Natural fibers, biopolymers, and biocomposites. Taylor \& Fracis Group Boca Raton: CRC Press; 2005:20-22.

8. Basuki T, Verona L. Manfaat Serat Sisal (Agave sisalana L.) dan Bambu (Bambusoideae) untuk Memenuhi Kebutuhan Masyarakat Modern. Jurnal Ilmu-Ilmu Pertanian “AGRIKA”.2017; 11(2):123-134.

https://doi.org/10.31328/ja.v11i2.487

9. Natarajan $\mathrm{N}$, Bharathidhasan $\mathrm{S}$, Thanigaivelan R dan Suresh P. Sisal Fiber / Glass Fiber Hybrid Nano Composite: The Tensile and Compressive Properties, 5th International \& 26th All India Manufacturing Technology, Design and Research Conference (AIMTDR 2014) December 12th-14th, 2014, IIT Guwahati, Assam, India (Aimtdr):1-6.

10. Basuki T, Verona L. Manfaat serat sisal (Agave sisalana L.) dan bambu (Bambusoideae) untuk memenuhi kebutuhan masyarakat modern. Jurnal Ilmu- Ilmu Pertanian "AGRIKA". 2017;11(2):123-134.

11. Kusumastuti A. Aplikasi serat sisal sebagai komposit polimer. Jurnal Kompetensi Teknik. 2009;1(1):9.

12. Chen PY, Chen CH, Kuo CC, Lee T Z, Kuo YH, Lee CK. Cytotoxic steroidal saponins from Agave sisalana. Planta med.2011;77:929-933.

https://doi.org/10.1055/s-0030$\underline{1250672}$

13. Ergina, Nuryanti S, Pursitasari ID. Uji Kualitatif Senyawa Metabolit Sekunder Pada Daun Palado (Agave angustifolia) yang Diesktraksi dengan Pelarut Air dan Etanol, J. Akad. Kim. 2014;3(3):165-172.
14. Dewi ZY, Nur A, Hertriani T. Efek Antibakteri dan Penghambatan Biofilm Ekstra Sereh (Cymbopogon nardus L.) terhadap Bakteri Streptococcus Mutans, Majalah Kedokteran Gigi Indonesia. 2015;1(2): 136-141.

https://doi.org/10.22146/majkedgiind. 9120

15. Rahman FA, Tetiana H, Trianna WH. Skrining Fitokimia dan aktivitas antibakteri ekstrak etanol daun sirih (Annona mucirata L.) pada S. mutans ATCC 35668. Majalah Kedokteran Gigi Indonesia.2017;3(1):1-7. https://doi.org/10.22146/majkedgiind. $\underline{11325}$

16. Thalib B, Herawati H. Konsentrasi ekstrak daun sirsak (Annona muricata) yang menghambat pertumbuhan $C$. albicans pada lempeng resin akrilik polimerisasi panas. Jurnal Dentofasial. 2013:12(3):159-163. 